\title{
Controlling the Unemployment Rate in South Sulawesi Province through Economic Growth, Provincial Minimum Wage and Inflation
}

\section{Ecces: \\ Economics Social and Development Studies}

\author{
Murtiadi Awaluddin ${ }^{1}$,* \\ Ilham $^{2}$, \\ Mutakallim Sijal ${ }^{3}$, \\ Andi Sylvana ${ }^{4}$, \\ 1,2,3 Faculty of Islamic Economics and Business, UIN Alauddin Makassar, Indonesia \\ ${ }^{4}$ Faculty of Economics and Business, Universitas Terbuka, Indonesia \\ Sultan Alauddin. 63, Gowa, South Sulawesi, Indonesia \\ e-mail: murtiadi.awaluddin@uin-alauddin.ac.id*
}

(Article history) Received: 2021-06-03, Revised: 2021-12-22, Accepted: 2021-12-25,

Available online: 2021-12-29, DOI: 10.24252/ecc.v7i1.13382,

Stable URL: http://journal.uin-alauddin.ac.id/index.php/ecc/index

\section{Abstract: Controlling the Unemployment Rate in South Sulawesi \\ Province through Economic Growth, Provincial \\ Minimum Wage (UMP) and Inflation}

Unemployment in South Sulawesi is very worrying and quite disturbing economic performance in this area. Although the government has made efforts to achieve growth based on employment and increase the minimum wage, conditions have not been able to reduce the unemployment rate itself. The novelty of this research is to try to dig deeper into the interrelationship of minimum wage setting policies, efforts to increase economic growth and efforts to control inflation by the government, to the unemployment phenomenon that occurs in South Sulawesi Province. This study aims to determine how the influence of economic growth, the provincial minimum wage and inflation on unemployment in South Sulawesi Province, Indonesia in 2005-2019. The type of research used is quantitative, namely the research method which is a scientific approach to economic decisions by using multiple linear regression analysis to find out how much influence the variables studied are. The results show that simultaneously economic growth, provincial minimum wages and inflation have a significant effect on unemployment in South Sulawesi Province. Partially, economic growth and provincial minimum wages have a significant negative effect on unemployment in South Sulawesi Province. Meanwhile, inflation has a positive and insignificant effect on unemployment in South Sulawesi Province. The implication of this research is that the government needs to increase quality and more inclusive economic growth based on expanding job opportunities and increasing human capital.

Keywords: Unemployment; Economic Growth; Minimum Wage; Inflation 
Murtiadi Awaluddin, I/ham, Rulyanti Susi Wardhani, Andi Sylvana, Controlling the Unemployment Rate in South Sulawesi

\section{INTRODUCTION}

South Sulawesi is one of 6 provinces on the island of Sulawesi that are not free from unemployment problems. The number of labor force in South Sulawesi in August 2019 was $4,030,400$ people, an increase of 42,371 people when compared to August 2018. The number of people working was 3,830,096 and those who were unemployed were 200,304. South Sulawesi's unemployment rate in the last 5 years has fluctuated from year to year although in aggregate unemployment decreased from 220,636 people in 2015 to 200,304 in 2019 or decreased by 20,332 people, but from 6 provinces on Sulawesi Island, South Sulawesi is in 2nd position with the highest unemployment rate (BPS Sulawesi Selatan, 2020). This confirms that unemployment in South Sulawesi is very concerning and quite disturbing economic performance in the area.

Figure 1. Provincial Unemployment Rate on Sulawesi Island in 2019

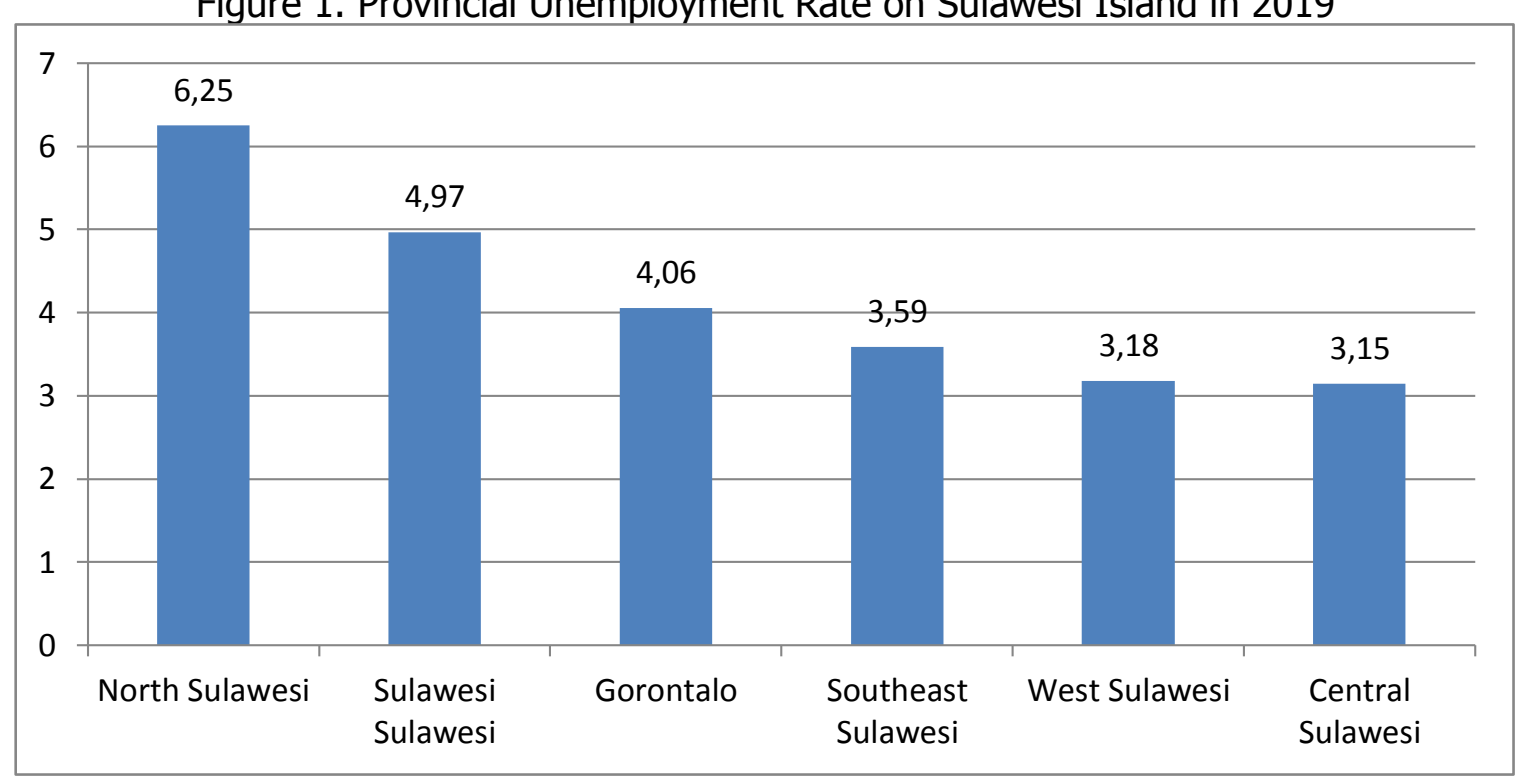

Source: BPS South Sulawesi (2020)

Based on the graph above, it can be seen that South Sulawesi Province is in the 2nd position, the highest unemployment rate is $4.97 \%, 0.91 \%$ adrift from Gorontalo in the 3rd position. If in order the highest unemployment rate on Sulawesi Island is North Sulawesi with 6.25\%, South Sulawesi 4.97\%, Gorontalo 4.06\%, Southeast Sulawesi 3.59\%, West Sulawesi 3.18\%, and Central Sulawesi 3.15\% (BPS Sulawesi Selatan, 2020). The large number that is publicly available will affect the economy in South Sulawesi.

The graph also shows that the unemployment problem in South Sulawesi is still in an alarming condition. In fact, South Sulawesi's Gross Regional Domestic Product (GRDP) is the 


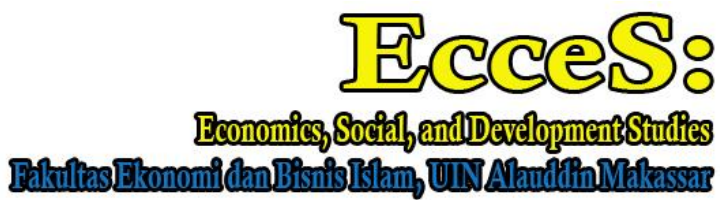

Volume 8 Number 2 Ed. Desember 2021 : page: 175-194 p-ISSN: 2407-6635 e-ISSN : 2580-5570

highest and even very far compared to other provinces in Sulawesi Island, as shown in the figure.

Figure 2 Province Gross Regional Domestic Product (GRDP)

in Sulawesi Island in 2019

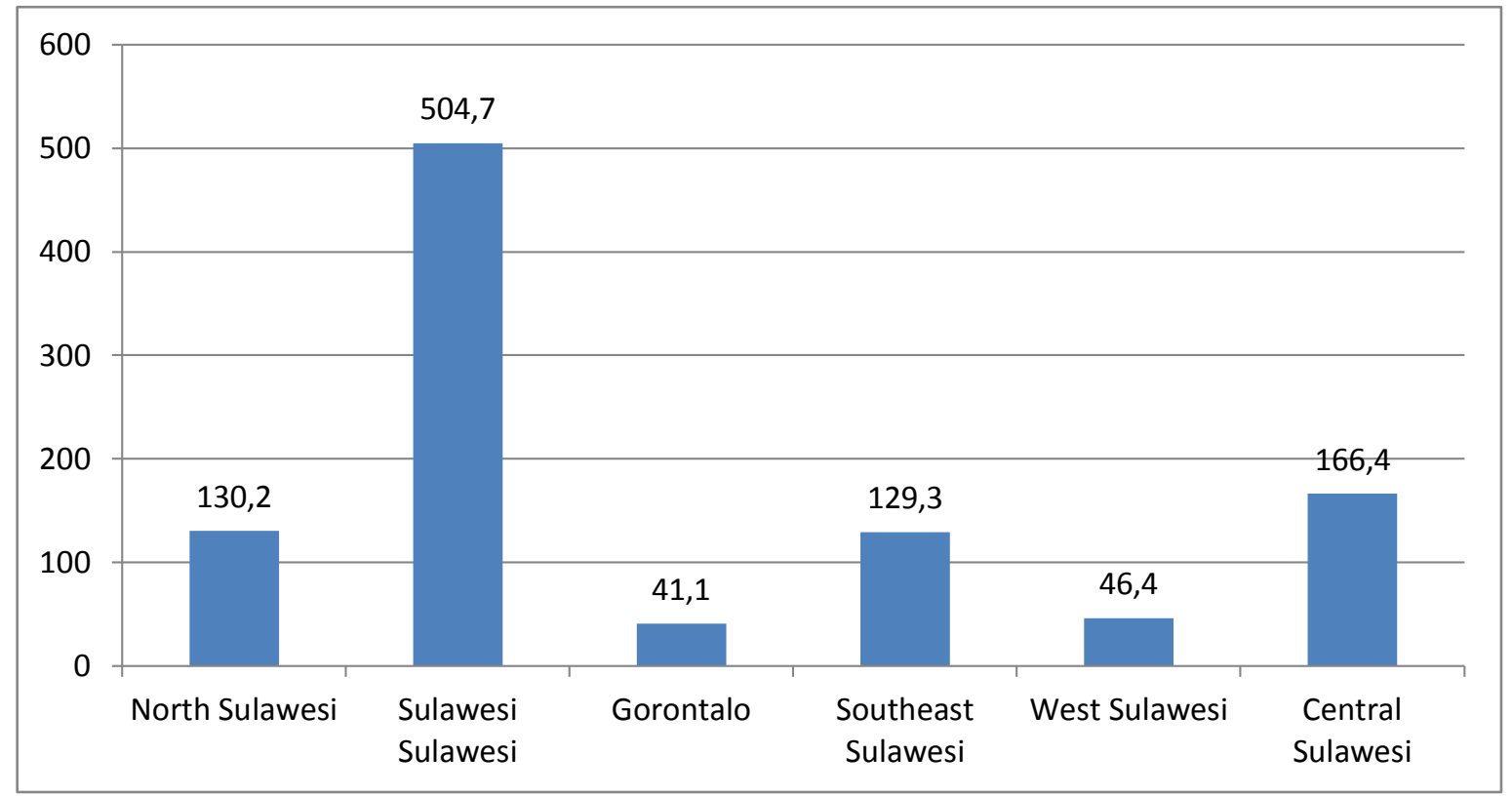

Source: BPS South Sulawesi (2020)

The Gross Regional Domestic Income (GRDP) of South Sulawesi Province when compared to other provinces on the island of Sulawesi, the difference is very striking, where the Gross Regional Domestic Income (GRDP) of South Sulawesi Province in 2019 is 504.7 Trillion, very far from the Province of South Sulawesi. Central Sulawesi is in second place with Gross Regional Domestic Revenue (GRDP) of 166.4 Trillion in the same year, followed by North Sulawesi Province at 130.2 Trillion, Southeast Sulawesi Province at 129.3 Trillion, West Sulawesi Province at 46.4 Trillion, and Gorontalo Province of 41.1 Trillion (BPS Sulawesi Selatan, 2020).

In addition to economic growth, several variables that also influence the unemployment rate are the minimum wage, this is found in various countries (Aisyah, 2020; Jäger et al., 2020; Leung, 2020; Chu et al., 2021; Fialová and Mysíková, 2021; Sotomayor, 2021). Generally, wages are rewards offered by entrepreneurs or investors for participation in production activities. The amount of wages depends on a number of factors, including the state of the company, political stability, security and the general economy, besides that wages are also regulated according to him which of course varies by region, from one 
Murtiadi Awaluddin, I/ham, Rulyanti Susi Wardhani, Andi Sylvana, Controlling the Unemployment Rate in South Sulawesi

company to another (Averett, et.al, 2020; Bossler, et.al, 2020; Health, 2020; Jäger et al., 2020; Renkin, et.al, 2020; Siregar, 2020; Thustrup et.al, 2020).

Figure 3 Total Minimum Wage for South Sulawesi Province 2015-2019

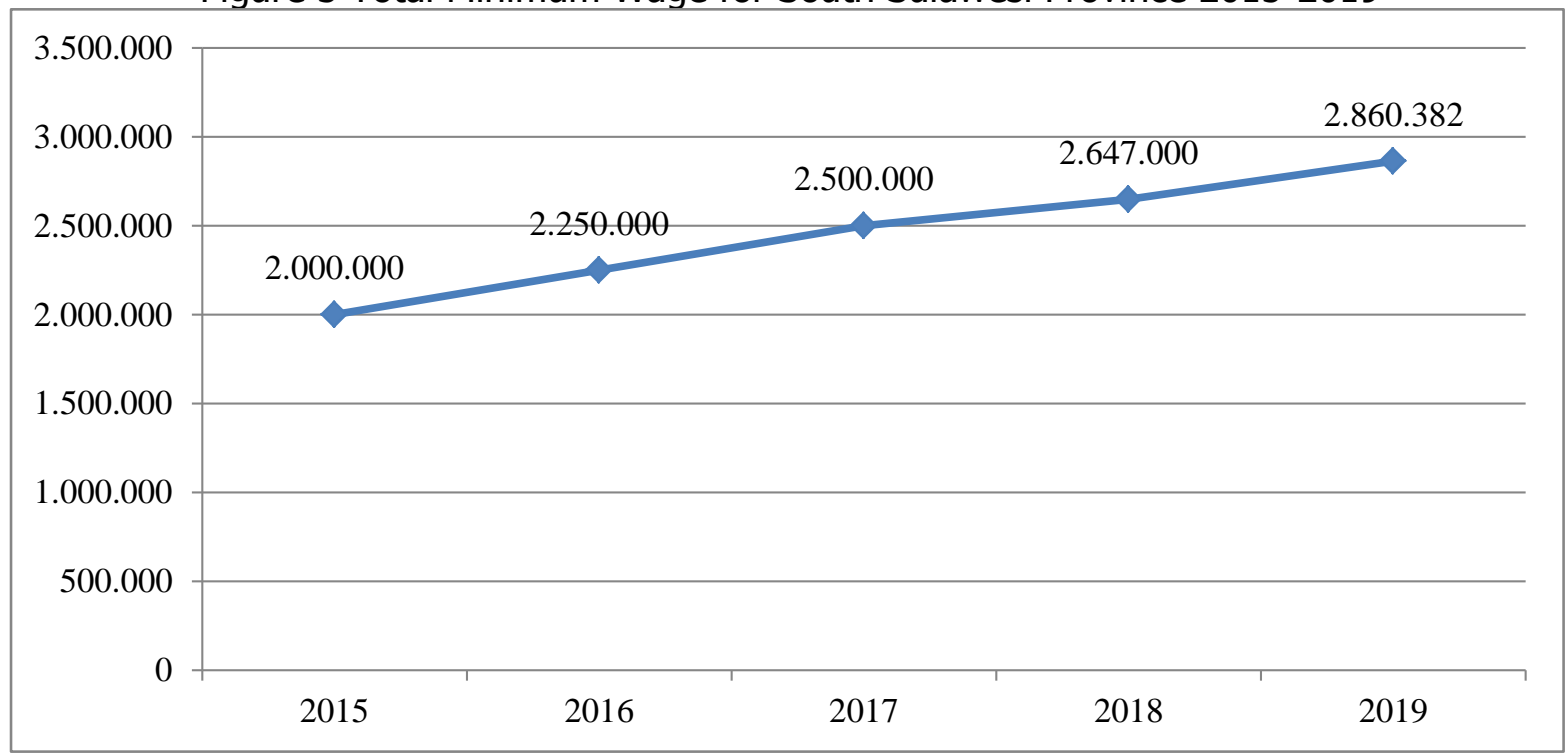

Source: BPS South Sulawesi (2020)

It can be seen that in the last 5 years the minimum wage of South Sulawesi Province has continued to increase, where in 2015 the minimum wage of Rp. 2,000,000 continued to increase until 2019 to Rp. 2,860,382 or an increase of Rp. 860,382. In determining the minimum wage, they must meet the standard of living ( $\mathrm{KHL}$ ) by taking into account productivity and labor growth, so it can be concluded that productivity and the economy in South Sulawesi continue to grow and encourage wage growth.

Another factor contributing to unemployment is inflation. Inflation is the process of increasing price growth in the economy. The inflation rate is the percentage increase in prices from one period to another. The higher the inflation rate, the lower the growth rate of a region. Based on the existing picture, it can be seen that in the last 5 years, the inflation rate of South Sulawesi Province has fluctuated quite a lot. Where in 2015 the inflation rate was $4.48 \%$, decreased in 2016 to $2.94 \%$, again increased in 2017 to $4.44 \%$, then decreased in 2018 to $3.57 \%$ and again decreased in 2019 to $2.97 \%$. This study aims to re-examine the effect of economic growth, Provincial Minimum Wage (UMP) and Inflation to determine unemployment in South Sulawesi Province. The novelty of this research is to try to dig deeper into the interrelationship of minimum wage setting policies, efforts to increase economic growth and efforts to control inflation by the government, to the unemployment phenomenon that occurs in South Sulawesi Province. 


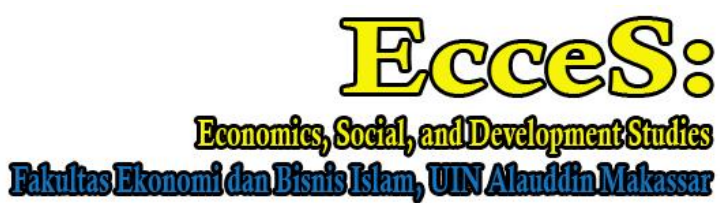

Volume 8 Number 2 Ed. Desember 2021 : page: 175-194 p-ISSN: 2407-6635 e-ISSN : 2580-5570

Figure 4 South Sulawesi Province Inflation Rate 2015-2019

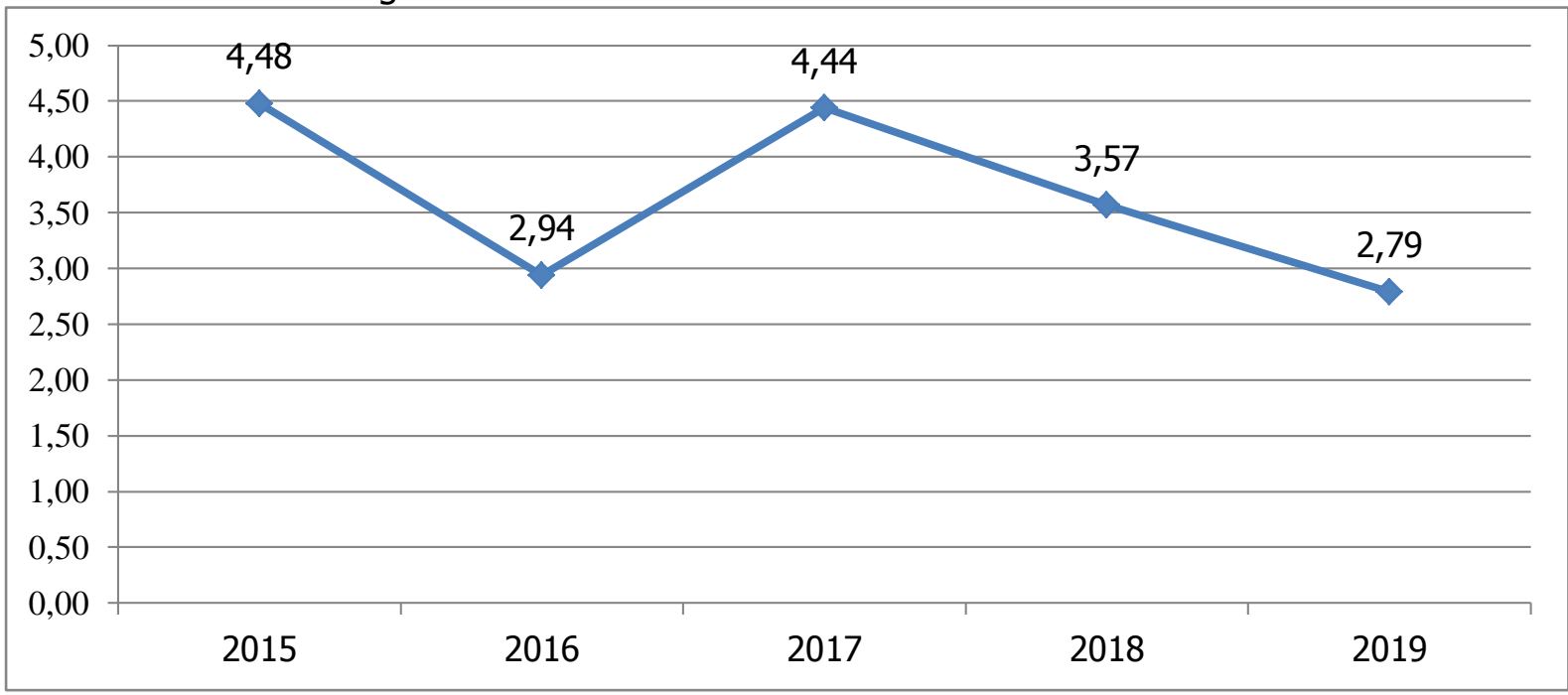

Source: BPS South Sulawesi (2020)

\section{LITERATUR REVIEW}

Rioux (2020) revealed that the problem of labor is a problem of productivity. Unproductive workers will be trapped in unemployment. As in the view of the classics, as emphasized by Adam Smith that labor productivity is the most important thing. From his indepth observations, Smith concludes that labor productivity can be increased through the division of labour. The division of labor will encourage specialization; people will choose to do the best according to their respective talents and abilities. The existence of specialization can actually mean that each person does not need to produce every item needed individually. However, it only produces one type of product. Excess goods for their own needs are exchanged (traded) in the market. Smith suggests that manufacturers divide the production process in a factory into different tasks for higher benefits. Each person performs a specific task. Due to the focus on one area, their productivity can increase. As a result, output will also increase. They are faster at doing tasks and do better because they have learned from past mistakes. Specialization leads to increased productivity and quality of finished products (Sidorovich, 2018; Van and Huu, 2018; Delanty, 2019; Smith et al., 2019; Stahl, 2019; Wallerstein, 2019; Wandel, 2019; Gennaioli et al., 2020; Rioux, et.al, 2020).

Unemployment is a complex problem that occurs in many countries in the world, which can be attributed to several economic indicators that influence the increase and decrease in unemployment (Islam et al., 2021; Khalid et al., 2021; Kitov, 2021; Maneejuk 
Murtiadi Awaluddin, I/ham, Rulyanti Susi Wardhani, Andi Sylvana, Controlling the Unemployment Rate in South Sulawesi

and Yamaka, 2021; Ningtias and Anwar, 2021; Padder and Mathavan, 2021; Ramzan, 2021; Vukmirović et al., 2021). Indicators that affect unemployment are economic growth, inflation and wage levels. According to research, Acharya and Mia (2020) stated that a high inflation rate could affect the increase in the number of unemployed in Indonesia. According to Mankiw (in Tumanoska, 2020) unemployment is a macroeconomic problem that affects humans directly and is the most severe. For most people, losing a job means a decrease in standard of living and psychological companions (Han, et.al, 2020; Jäger et al., 2020; Mansi et al., 2020; Papadakis et al., 2020; Parolin, et.al, 2020; Prasetyo and Kistanti, 2020; Tumanoska, 2020).

So it is not surprising that unemployment is a frequent topic of political debate and politicians often claim that the policies they propose will help create jobs. A person who does not work, but is not actively looking for work does not fall into the unemployment category. For example, a woman who has become a housewife chooses not to work because she prefers to take care of housework and her family rather than looking for work outside the home. Louail and Riache, (2019) Unemployment is a condition where someone who belongs to the labor force wants to get a job but has not been able to get it. According to the ILO (International Labor Organization) concept, open unemployment is known as unemployment. This unemployment includes residents who are looking for work, residents who are preparing for business, residents who are not looking for work because they feel it is impossible to get a job but have not started work (Aisyah and Sulastri, Al-Haddad et al., 2019; Cigu, Agheorghiesei and Toader, 2019; Grotlüschen et al., 2019; Kronauer, 2019; McArthur and Reeves, 2019; Terziev, 2019).

Contrary to Keynes' view (in Henrique et al., 2020) states that macroeconomic trends can influence the behavior of microeconomic individuals. In contrast to the classical economist theory which states that the economic process is based on the development of potential output. Keynes emphasized the importance of aggregate demand as the main driving factor for the economy, especially in a sluggish economy (Aspromourgos, 2019; Crotty, 2019; Fuller, 2019; Petrović, 2019; Sarı Aksakal, 2020). Keynes argued that government policies could be used to increase demand at the macro level in order to reduce unemployment and inflation. If the government increases its spending, the money circulating in the community will increase so that people will be encouraged to shop and increase their demand, aggregate demand will increase (Modulates and Baviour, 2015; Franke et al., 2016; Khairuzzaman, 2016; Singerman, 2016, 2016; Spiritus and Approach, 2016; To and Of, 2016; Üşenmez, 2017; Cömert, 2019; Festré, 2019; Han and goleman, 


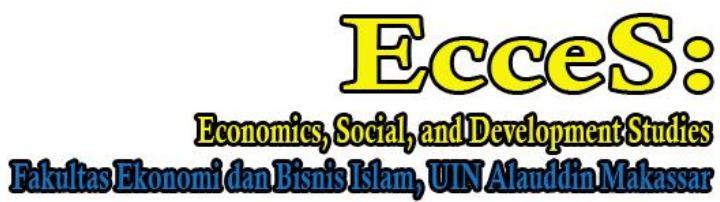

Volume 8 Number 2 Ed. Desember 2021 : page: 175-194 p-ISSN: 2407-6635 e-ISSN : 2580-5570

daniel; boyatzis, Richard; Mckee, 2019). In addition, savings will also increase so that it can be used as investment capital, and economic conditions will return to normal levels. The conclusion from Keynes's theory is that there is no automatic tendency to move output and employment to conditions of full employment (Beaud; Quiggin, Crotty, 1983; Heilbroner, 1984; BLINDER, 1988; Davis, 1994; Eisenschitz and Gough, 1996; Dau-Schmidt, 2012; Bellofiore, 2013; 2014; Oner, 2015; Modulates, 2015).

\section{METHODS}

This type of research is quantitative research, namely research methods which are a scientific approach to economic decisions. This quantitative data is in the form of time series data, which is data arranged according to time on a certain variable. In this study, quantitative data sources were collected through secondary data from the Central Statistics Agency (BPS) of South Sulawesi. In addition, there are also literature studies, both books, journal publications, and data sources published by certain agencies. Unemployment rate data becomes the dependent variable. Meanwhile, the independent variables include economic growth in percent units, the Provincial Minimum Wage (UMP) based on rupiah units, and inflation based on percent units. The location of this research is South Sulawesi through the Central Statistics Agency (BPS) of South Sulawesi from 2009 - 2019.

The analytical method used in this research is the Multiple Regression model analysis. The aim is to calculate the estimated parameters and to see whether the independent variable is able to explain the dependent variable and has an effect. The variable to be estimated is the dependent variable, while the influencing variables are the independent variables. This method shows the relationship between the independent variable and the dependent variable, used to see the research problem being studied. The technique used is the Exponential Function equation with Multiple Regression, as follows;

$Y=\beta 0+\beta 1 X 1+\beta 2 X 2+\beta 3 X 3+e$

To estimate the regression coefficient, a transformation is carried out to linear form using the partial natural logarithm (In) into the model so that the following equation is obtained:

$$
\operatorname{Ln} Y=\beta 0+\beta 1 \ln X 1+\beta 2 \ln X 2+\beta 3 \ln X 3+\mu
$$


Murtiadi Awaluddin, I/ham, Rulyanti Susi Wardhani, Andi Sylvana, Controlling the Unemployment Rate in South Sulawesi

Where, $\mathrm{Y}$ is unemployment. 0 is the Intercept or constant number, $1,2,3$ is the value of the Regression Coefficient, $\mathrm{X} 1$ is economic growth; while $\mathrm{X} 2$ is Minimum Wage, $\mathrm{X} 3$ is inflation ; Ln is Natural Logarithm, $\mathrm{t}$ is Time Series/cross section; is the residual.

\section{RESULT AND DISCUSSION}

Based on the existing partial test table ( $t$ test), the coefficient of Economic Growth is -1.154 with a significance value of 0.005 and is stated to be smaller than the significance level used in this study, namely $0.05(0.005<0.05)$, which means Economic Growth has a significant negative effect on unemployment. The comparison between the tcount value and the ttable value, with a significance level of 0.05 with a degree of freedom (df) $15-4=11$ is 2.200 so that tcount $<$ ttable $(-3.451<2.200)$ so it can be concluded that the variable Economic Growth has a significant negative effect. against unemployment. The value of the coefficient of Economic Growth is -1.154 , which means that every $1 \%$ increase in Economic Growth will reduce Unemployment by $1.154 \%$.

Table 1. Multiple Regression Analysis Results

\begin{tabular}{lccccc}
\hline Model & \multicolumn{1}{c}{$\begin{array}{c}\text { Unstandardized } \\
\text { Coefficients }\end{array}$} & $\begin{array}{c}\text { Standardized } \\
\text { Coefficients }\end{array}$ & $\mathrm{T}$ & Sig. \\
\hline (Constant) & $\mathrm{B}$ & Std. Error & & & \\
\hline Growth & 20.294 & 1.245 & & 16.297 & .000 \\
\hline Minimum Wage & -1.154 & .334 & -.378 & -3.451 & .005 \\
\hline Inflation & -.402 & .079 & -.072 & -5.056 & .000 \\
\hline Source: Primaty & .057 & .085 & .091 & .670 & .517
\end{tabular}

Source: Primary data output after processing, 2020; (Murtiadi, 2020)

Associated with the variable Provincial Minimum Wage (UMP) of -0.402 with a significance value of 0.00 and is stated to be smaller than the significance level used in this study, namely $0.05(0.00<0.05)$, which means that the Provincial Minimum Wage variable has significant negative effect on unemployment. The comparison between the tcount and ttable values with a significance level of 0.05 with df $15-4=11$ is 2,200 so that tcount ttable $(-5.056<2.200)$ so that it can be concluded that the Provincial Minimum Wage (UMP) variable has a significant negative effect on unemployment. The coefficient value of the Provincial Minimum Wage is -0.402 , which means that every $1 \%$ increase in the Provincial Minimum Wage will reduce Unemployment by $0.402 \%$. 


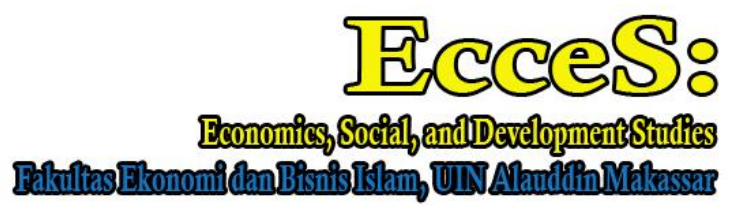

Volume 8 Number 2 Ed. Desember 2021 : page: 175-194 p-ISSN: 2407-6635 e-ISSN : 2580-5570

Next, the inflation variable is 0.057 with a positive sign meaning that the inflation variable has a positive effect on unemployment, while the significance value is 0.517 and is stated to be greater than the significance level used in this study, which is $0.05(0.517>$ 0.05 ) so it can be concluded that Inflation variable has a positive and insignificant effect on unemployment. The value of the inflation coefficient is 0.057 , which means that every $1 \%$ increase in inflation will increase unemployment by 0.057 .

Figure 5. of Data Normality Test Results

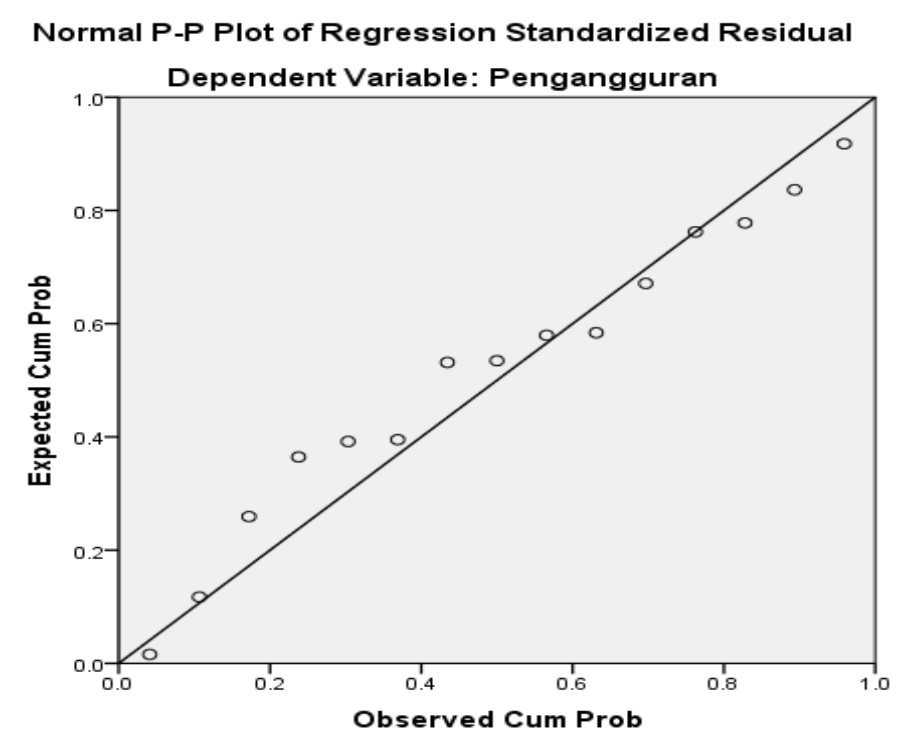

Source: Primary data output after processing, 2020; (Murtiadi, 2020)

Normal P-P Plots can be detected by the spread of the data (points) on the diagonal axis in the graph. If the data is spread around the line, it indicates that the regression model meets the assumption of normality. On the other hand, if the data spreads far from the diagonal line in the graph, the regression model does not meet the assumption of normality. The results of the P-Plot test above the data spread around the diagonal line so that it meets the assumption of normality.

\section{Multicollinearity Test}

The multicollinearity test aims to test the correlation between independent (independent) variables, to see whether there is multicollinearity with the following conditions: The tolerance value commonly used to indicate the presence of multicollinearity is the Tolerance value $>0.10$ or equal to the VIF value $<10$.

The table shows the results that the VIF value of the Economic Growth variable is 1,081 Provincial Minimum Wage is 1,740 , Inflation is 1,647 , all variables show a number less 
Murtiadi Awaluddin, I/ham, Rulyanti Susi Wardhani, Andi Sylvana, Controlling the Unemployment Rate in South Sulawesi

than 10 (VIF value < 10). Meanwhile, the Tolerance value $>0.10$, namely Economic Growth of 0.925 , Provincial Minimum Wage of 0.575 and Inflation of 0.607 , so it can be concluded that the three independent variables do not experience multicollinearity.

The results of the multicollinearity test referred to in this study are as follows:

Table 2 of Multicollinearity Test Results

\begin{tabular}{lccccc}
\hline \multirow{2}{*}{ Model } & \multicolumn{3}{c}{ Correlations } & \multicolumn{2}{c}{ Collinearity Statistics } \\
\cline { 2 - 6 } & Zero-order & Partial & Part & Tolerance & VIF \\
\hline (Constant) & & & & & \\
\hline Growth & -.582 & -.721 & -.363 & .925 & 1.081 \\
\hline Minimum Wage & -.862 & -.836 & -.532 & .575 & 1.740 \\
\hline Inflation & .586 & .198 & .071 & .607 & 1.647 \\
\hline
\end{tabular}

Source: Primary data output after processing, 2020; (Murtiadi, 2020)

\section{Heteroscedasticity Test}

The purpose of heteroscedasticity testing is to see whether in a regression model there is an inequality of variance from the residuals of one observation to another observation. It can also be interpreted that this test aims to see whether the confounding variables have the same variance or not. Detecting heteroscedasticity by looking at the graph plot between the predicted value of the dependent variable, namely ZPRED and the residual SRESID. Detection can be proven by looking at the scatterplot graph between the predicted $Y$-axis ZPRED and the actual X-axis SRESID. The test results are shown in the following graph.

Figure 6. Heteroscedasticity Test Results

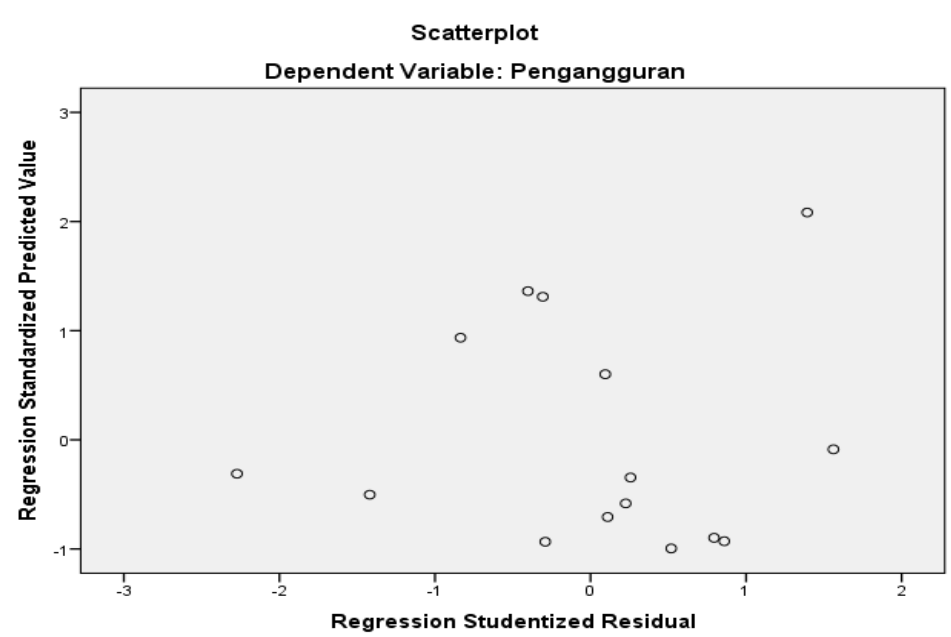

Source: Primary data output after processing, 2020; (Murtiadi, 2020) 


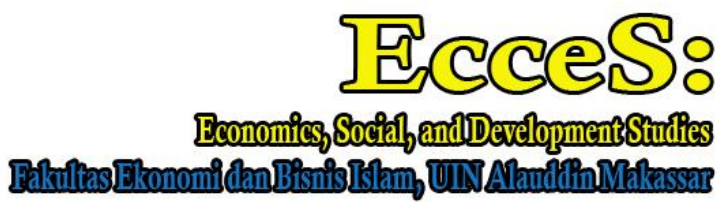

Volume 8 Number 2 Ed. Desember 2021 : page: 175-194 p-ISSN: 2407-6635 e-ISSN : 2580-5570

The analysis results contained in the scatterplot graph do not show a clear pattern and there are dots that spread randomly above and below the number 0 , and do not form a certain clear pattern. So it can be concluded that there is no heteroscedasticity between variants of the residuals of an observation.

\section{The Effect of Economic Growth on Unemployment}

The results of this study indicate that the variable economic growth has a significant negative effect on unemployment. So it can be concluded that any increase in economic growth will reduce unemployment in South Sulawesi Province. Economic growth, namely an increase in production or an increase in national income. The higher the national income, the greater the expectation of opening new production openings which of course will absorb new workers, meaning that if employment increases, unemployment will automatically decrease.

This is in line with research Saputri and Anwar (2019) who found that the variable economic growth, often cannot be an absolute barometer in terms of looking at unemployment. Both can run linearly, if the growth that occurs is exclusive and unable to reduce the unemployment rate itself. As a result, the unemployment rate remains high, in the midst of achieving growth. Ideally, accelerated growth should be able to contribute to efforts to reduce unemployment (Arabiyat et al., 2020; Geiger et al., 2020; Jakob et al., 2020; Kukić, 2020; Rahman and Velayutham, 2020; Saputri and Anwar, 2019b)

\section{The Effect of Provincial Minimum Wage on Unemployment}

The variable of the provincial minimum wage has a significant negative effect on unemployment. So it can be ascertained that the increase in the Provincial Minimum Wage (PMU) will reduce the unemployment rate in South Sulawesi Province. According to Phillips on the characteristics of changes in the wage rate by the British between 1861-1957. The study looked at the relationship between the unemployment rate and the wage level. The conclusion of this study is that there is a negative relationship between wage growth and the unemployment rate (Adelowokan et al., 2019; Angus C Chu et al., 2021; Islam et al., 2021; Khalid et al., 2021; Kitov, 2021; Louail and Riache, 2019; Papadakis et al., 2020; Ramzan, 2021; Terziev, 2019; Tumanoska, 2020)

This is in line with research Panjawa (2015) where the minimum wage variable has a significant negative effect on unemployment, it seems that the minimum wage is able to 
Murtiadi Awaluddin, I/ham, Rulyanti Susi Wardhani, Andi Sylvana, Controlling the Unemployment Rate in South Sulawesi

reduce unemployment. It is undeniable that the minimum wage, which is based on the welfare of the workforce, is able to move the economy of a region. The minimum wage, which is able to represent the welfare of the workforce, can certainly have a positive impact in terms of reducing unemployment (Aisyah and Sulastri, n.d.; Grotlüschen et al., 2019; Gufron and Utomo, 2020; Health, 2020; Mansi et al., 2020; Padder and Mathavan, 2021; Panjawa, 2015; Parolin et al., 2020).

\section{The Effect of Inflation on Unemployment}

The inflation variable has a positive and insignificant effect. This means that the inflation variable cannot explain the significant effect on unemployment in South Sulawesi Province. In the Philips curve it is clear that there is a negative relationship between the inflation growth rate and the unemployment growth rate (unemployment rate). The Philips curve shows that price stability and high job opportunities cannot occur at the same time, because there must be a trade-off. If you want to get high job opportunities, it means that every worker must also be willing to accept the burden of high inflation (Ahmed, 2020; DERELİ, 2019; Petrosky-Nadeau and Valletta, 2019; Sahnoun and Abdennadher, 2019; Selim and Hassan, 2019; Tenzin, 2019).

This is in line with research Qomariyah, (2013) where the inflation variable has a positive effect on unemployment. Based on a descriptive analysis of East Java's inflation in general, based on rising commodities, rising oil prices and health costs, not as a result of increased demand, as in recent years, with inflation as the main effect. The findings of this study are not in line with the theory behind the research, namely the Phillips curve theory which explains that there is an inverse/negative relationship between inflation and unemployment. Milton Friedman in 1976 stated that the basic theory of the Phillips curve only applies in the short run because it applies a sticky price, whereas in the long run inflation has a positive effect in the flexible period with respect to price-yield inflation (Azam and Khan, 2020; Bernd and Neumeier, 2020; Lv et al., 2019; Mansi et al., 2020; NGOC, 2020; Szafranek and Hałka, 2019; Wahyuningsih et al., 2020).

\section{CONCLUSION}

Based on the research results. Based on the research that has been done, it can be concluded that the research results are as follows: 1). Economic Growth and Provincial Minimum Wage (UMP), each have a negative and significant effect on unemployment in South Sulawesi Province so that every increase in Economic Growth and Provincial Minimum 


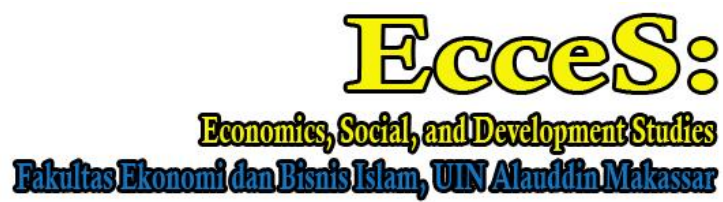

Volume 8 Number 2 Ed. Desember 2021 : page: 175-194 p-ISSN: 2407-6635 e-ISSN : 2580-5570

Wage (UMP), will reduce unemployment in South Sulawesi Province, 2). On the other hand, inflation has a positive and insignificant effect on unemployment so that the inflation variable cannot explain its significant effect on unemployment in South Sulawesi Province. Simultaneously economic growth, the Provincial Minimum Wage (UMP) and inflation have a significant effect on the unemployment rate in South Sulawesi Province, which means that simultaneously the three independent variables can explain their significant effect on Unemployment in South Sulawesi Province.

The implications of this research include; 1 ). The government is expected to increase and create quality economic growth, namely economic growth that is not only high, but also able to make real sectors develop so as to create public welfare and expand job opportunities, 2). The government is expected to be able to improve the quality of human capital of the workforce by providing training and improving the quality of education. By improving the quality of the workforce, it is hoped that it will increase labor productivity so that they can get higher wages and further increase economic activity so that they can create new jobs.

\section{REFERENCES}

Acharya, S., Mia, M.I., 2020. Inflation, Growth, and Distribution Nexus in Post-Transition and Emerging Economies of South Asia. Econ. Altern. 368-383.

Adelowokan, O.A., Maku, O.E., Babasanya, A.O., Adesoye, A.B., 2019. Unemployment, poverty and economic growth in Nigeria. J. Econ. Manag. 35, 5-17.

Ahmed, B., 2020. Inflation and Unemployment in Pakistan: An Empirical Analysis. Pakistan

Soc. Sci. Rev. 4, 306-318.

Aisyah, S., Business, I., 2020. Tracing the Labor Absorption Rate in the Medium and Large Industrial Sectors EcceS : Economics Social and Development Studies 7, 220-239.

Aisyah, S., Sulastri, S., n.d. Tracing the Labor Absorption Rate in the Medium and Large Industrial Sectors. EcceS (Economics, Soc. Dev. Stud. 7, 220-239.

Al-Haddad, L., Sial, M.S., Ali, I., Alam, R., Khuong, N.V., Khanh, T.H.T., 2019. The role of small and medium enterprises (SMEs) in employment generation and economic growth: a study of marble industry in emerging economy. Int. J. Financ. Res. 10, 174-187. Arabiyat, T.S., Mdanat, M., Samawi, G., 2020. Trade Openness, Inclusive Growth, And Inequality: Evidence From Jordan. J. Dev. Areas 54. 
Murtiadi Awaluddin, I/ham, Rulyanti Susi Wardhani, Andi Sylvana, Controlling the Unemployment Rate in South Sulawesi

Aspromourgos, T., 2019. The Past and Future of Keynesian Economics: A Correction. Hist. Econ. Rev. 74, 81-83.

Averett, S.L., Smith, J.K., Wang, Y., 2020. Minimum wages and the health of immigrants' children. Appl. Econ. Lett. 00, 1-8.

Azam, M., Khan, S., 2020. Threshold effects in the relationship between inflation and economic growth: Further empirical evidence from the developed and developing world. Int. J. Financ. Econ.

Beaud, M., n.d. A History and Dictionary of Major Economists Translated from French by Valérie Cauchemez with the participation of Eric Litwack.

Bellofiore, R., 2013. A heterodox structural Keynesian: Honouring Augusto Graziani. Rev. Keynes. Econ. 1, 425-430.

Bernd, B., Neumeier, F., 2020. Explaining central bank trust in an inflation-targeting country: the case of the Reserve Bank of New Zealand 1-22.

BLINDER, A.S., 1988. The Fall and Rise of Keynesian Economics. Econ. Rec. 64, 278-294.

Bossler, M., Oberfichtner, M., Schnabel, C., 2020. Employment Adjustments Following Rises and Reductions in Minimum Wages: New Insights From a Survey Experiment. Labour 34, 323-346.

BPS, 2020. Sulawesi Selatan Province In Figures 2020.

Chu, Angus C, Cozzi, G., Fan, H., Furukawa, Y., 2021. Inflation, unemployment, and economic growth in a Schumpeterian economy. Scand. J. Econ. 123, 874-909.

Chu, Angus C., Fan, H., Furukawa, Y., Kou, Z., Liu, X., 2021. Minimum Wages, Import Status, and Firms' Innovation: Theory and Evidence From China. Econ. Inq. 59, 441458.

Cigu, E., Agheorghiesei, D.T., Toader, E., 2019. Transport infrastructure development, public performance and long-run economic growth: a case study for the Eu-28 countries. Sustainability $11,67$.

Cömert, M., 2019. Revival of Keynesian Economics or Greening Capitalism: "Green Keynesianism." Sosyoekonomi 27, 129-144.

Crotty, J., 2019. Keynes against capitalism : his economic case for liberal socialism.

Crotty, J.R., 1983. On Keynes and Capital Flight. J. Econ. Lit. 21, 59-65.

Dau-Schmidt, K.G., 2012. Keynes was right! Indiana Law J. 87, 59-62.

Davis, J.B., 1994. by D . Moggridge 10, 359-364.

Delanty, G., 2019. The future of capitalism: Trends, scenarios and prospects for the future. J. Class. Sociol. 19, 10-26. 


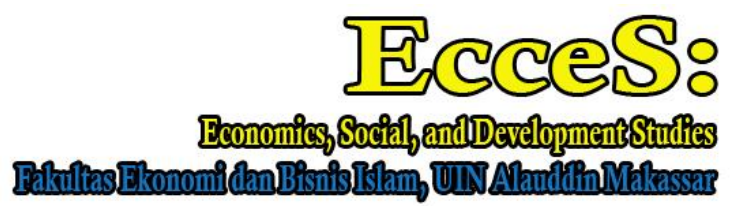

Volume 8 Number 2 Ed. Desember 2021 : page: 175-194 p-ISSN: 2407-6635 e-ISSN : 2580-5570

DERELİ, D.D., 2019. The Relationship Between Inflation and Unemployment in Turkey: An ARDL Bounds Testing Approach. Kırklareli Üniversitesi İktisadi ve İdari Bilim. Fakültesi Derg. 8, 246-257.

Eisenschitz, A., Gough, J., 1996. The contradictions of neo-keynesian local economic strategy. Rev. Int. Polit. Econ. 3, 434-458.

Festré, A., 2019. Michael Polanyi ' Vision of Economics: Spanning Hayek and Keynes. Fialová, K., Mysíková, M., 2021. Minimum Wage and Youth Employment in Regions of the Visegrád Countries. East. Europ. Econ. 59, 82-102.

Franke, N., Schirg, F., Reinsberger, K., Published, A., Franke, N., Schirg, F., Reinsberger, K., 2016. ePub WU Institutional Repository findings 0-64.

Fuller, E.W., 2019. Keynes and the ethics of socialism. Q. J. Austrian Econ. 22, 139-180. Geiger, M., Mayer, E., Scharler, J., 2020. Inequality and the business cycle: evidence from U.S. survey data. Appl. Econ. 52, 3418-3435.

Gennaioli, N., Gollin, D., Lagakos, D., Matvos, G., Mestieri, M., Arellano, M., Mas, J.P., Fernandez-val, I., Saidi, F., 2020. The process of economic development is characterized by a reallocation of production factors from the agricultural to the industrial and service sectors . Economic historians have argued that in the first industrialized countries technical improvements in 1037-1094.

Grotlüschen, A., Buddeberg, K., Redmer, A., Ansen, H., Dannath, J., 2019. Vulnerable subgroups and numeracy practices: How poverty, debt, and unemployment relate to everyday numeracy practices. Adult Educ. Q. 69, 251-270.

Gufron, M.B.H., Utomo, Y.P., 2020. Analisis Pengaruh Upah Minimum, Pdrb, Jumlah

Penduduk Dan Indeks Pembangunan Manusia Terhadap Jumlah Pengangguran Di Jawa Timur Tahun 2018.

Han, E.S., goleman, daniel; boyatzis, Richard; Mckee, A., 2019. 済無No Title No Title. J.

Chem. Inf. Model. 53, 1689-1699.

Han, J., Meyer, B.D., Sullivan, J.X., 2020. Income and Poverty in the COVID-19 Pandemic.

National Bureau of Economic Research.

Health, P., 2020. in It Sc It Sc 27708, 1-19.

Heilbroner, R.L., 1984. Economics and Political Economy: Marx, Keynes, and Schumpeter. J.

Econ. Issues 18, 681-695. 
Murtiadi Awaluddin, Ilham, Rulyanti Susi Wardhani, Andi Sylvana, Controlling the Unemployment Rate in South Sulawesi

Henrique, F., Terra, B., Filho, F.F., Cezar, P., Fonseca, D., 2020. Review of Political Economy, v. 32, n. 3, 2020 1-14.

Islam, M.M., Alharthi, M., Murad, M.W., 2021. The effects of carbon emissions, rainfall, temperature, inflation, population, and unemployment on economic growth in Saudi Arabia: An ARDL investigation. PLoS One 16, e0248743.

Jäger, S., Schoefer, B., Young, S., Zweimüller, J., 2020. Wages and the value of nonemployment. Q. J. Econ. 135, 1905-1963.

Jakob, M., Lamb, W.F., Steckel, J.C., Flachsland, C., Edenhofer, O., 2020. Understanding different perspectives on economic growth and climate policy. Wiley Interdiscip. Rev. Clim. Chang. 11, 1-17.

Khairuzzaman, M.Q., 2016. No Title血清及尿液特定蛋白检测在糖尿病肾病早期沴断中的意义. Khalid, W., Akalpler, E., Khan, S., Shah, N.H., 2021. The Relationship Between Unemployment and Economic Growth in South Africa: VAR Analysis. Forman J. Econ. Stud. 17.

Kitov, I., 2021. The link between unemployment and real economic growth in developed countries. arXiv Prepr. arXiv2104.04595.

Kronauer, M., 2019. 'Social exclusion'and 'underclass'-new concepts for the analysis of poverty. In: Empirical Poverty Research in a Comparative Perspective. Routledge, pp. 51-76.

Kukić, L., 2020. Origins of regional divergence: economic growth in socialist Yugoslaviat. Econ. Hist. Rev. 73, 1097-1127.

Leung, J.H., 2020. Minimum Wage and Real Wage Inequality: Evidence from Pass-Through to Retail Prices. Rev. Econ. Stat. 1-47.

Louail, B., Riache, S., 2019. Asymmetry relationship between economic growth and unemployment rates in the Saudi economy: Application of Okun's law during the period. Int. J. Adv. Appl. Sci. 83-88.

Lv, L., Liu, Z., Xu, Y., 2019. Technological progress , globalization and low- inflation: Evidence from the United States 1-19.

Maneejuk, P., Yamaka, W., 2021. The Impact of Higher Education on Economic Growth in ASEAN-5 Countries. Sustainability 13, 520.

Mansi, E., Hysa, E., Panait, M., Voica, M.C., 2020. Poverty-A Challenge for Economic Development? Evidences from Western Balkan Countries and the European Union. Sustainability $12,7754$. 


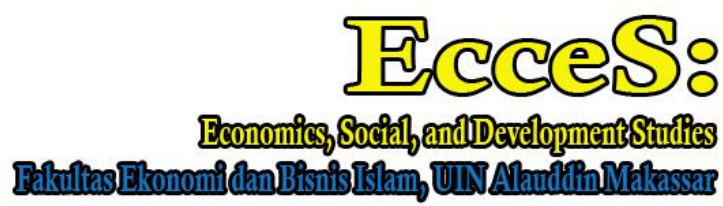

Volume 8 Number 2 Ed. Desember 2021 : page: 175-194 p-ISSN: 2407-6635 e-ISSN : 2580-5570

McArthur, D., Reeves, A., 2019. The rhetoric of recessions: how British newspapers talk about the poor when unemployment rises, 1896-2000. Sociology 53, 1005-1025.

Modulates, P., Behaviour, S., 2015. This is an Accepted Manuscript of an article published by Taylor \& Francis in Journal of Cognitive Psychology, available online: 1-26.

NGOC, B.H., 2020. The asymmetric effect of inflation on economic growth in Vietnam:

Evidence by nonlinear ARDL approach. J. Asian Financ. Econ. Bus. 7, 143-149.

NIKODYM, T., 2014. The Economic Causes of War and Changes in Post-War Economic

Thought: From Keynes to Beneš. Cent. Eur. Pap. 2, 79-94.

Ningtias, E.N.A., Anwar, A.F., 2021. Mengukur Dampak Pengangguran, Tingkat Pendidikan,

Upah Minimum, dan Pengeluaran Per Kapita terhadap Kemiskinan di Kota Makassar.

Bull. Econ. Stud. 1.

Oner, E., 2015. Comparative Interpretation of Classical and Keynesian Fiscal Policies

(Assumptions, Principles and Primary Opinions). Int. J. Financ. Bank. Stud. 4, 11-20.

Padder, A.H., Mathavan, B., 2021. The Relationship between Unemployment and Economic

Growth in India: Granger Causality Approach. NVEO-NATURAL VOLATILES Essent. OILS Journal| NVEO 1265-1271.

Panjawa, J.L., 2015. Analisis Determinan Tingkat Pengangguran Se Eks Karesidenan Sur

Akarta Di Jawa Tengah Tahun 1999-2013.

Papadakis, N., Amanaki, E., Drakaki, M., Saridaki, S., 2020. Employment/ unemployment, education and poverty in the Greek Youth, within the EU context. Int. J. Educ. Res. 99, 101503.

Parolin, Z., Curran, M., Wimer, C., 2020. The CARES Act and Poverty in the COVID-19 crisis:

Promises and pitfalls of the recovery rebates and expanded unemployment benefits.

Center on Poverty and Social Policy, Columbia University.

Petrosky-Nadeau, N., Valletta, R.G., 2019. Unemployment: lower for longer? FRBSF Econ.

Lett. 21.

Petrović, J., 2019. Economic Thought of Friedrich List, Gunnar Myrdal and John Maynard Keynes, and Its Applicability in Transition Economies. Facta Univ. Ser. Econ. Organ. 16, 075.

Prasetyo, P.E., Kistanti, N.R., 2020. Human capital, institutional economics and entrepreneurship as a driver for quality \& sustainable economic growth. Entrep. Sustain. Issues 7, 2575. 
Murtiadi Awaluddin, I/ham, Rulyanti Susi Wardhani, Andi Sylvana, Controlling the Unemployment Rate in South Sulawesi

Qomariyah, I., 2013. Pengaruh tingkat inflasi dan pertumbuhan ekonomi terhadap tingkat pengangguran di jawa timur. J. Pendidik. Ekon. 1.

Quiggin, J., n.d. Risk \& Sustainable Management Group Economic liberalism : fall , revival and resistance.

Rahman, M.M., Velayutham, E., 2020. Renewable and non-renewable energy consumptioneconomic growth nexus: New evidence from South Asia. Renew. Energy 147, 399-408.

Ramzan, M., 2021. Impact of Inflation and Unemployment on Economic Growth of Pakistan. Eur. J. Bus. Manag. Res. 6, 282-288.

Renkin, T., Montialoux, C., Siegenthaler, M., 2020. The Pass-Through of Minimum Wages into US Retail Prices: Evidence from Supermarket Scanner Data. Rev. Econ. Stat. 1-99.

Rioux, S., LeBaron, G., Verovšek, P.J., 2020. Capitalism and unfree labor: a review of Marxist perspectives on modern slavery. Rev. Int. Polit. Econ. 27, 709-731.

Sahnoun, M., Abdennadher, C., 2019. Causality between inflation, economic growth and unemployment in North African countries. Econ. Altern. 1, 77-92.

Saputri, S.F., Anwar, P.H., 2019a. Interelasi Pertumbuhan Ekonomi, Belanja Pendidikan dan Pengangguran Terhadap Tingkat Kemiskinan. EcceS (Economics, Soc. Dev. Stud. 6, 91110.

Saputri, S.F., Anwar, P.H., 2019b. Interelasi Pertumbuhan Ekonomi, Belanja Pendidikan dan Pengangguran Terhadap Tingkat Kemiskinan. EcceS (Economics, Soc. Dev. Stud. 6, 91. Sarı Aksakal, B., 2020. World Bank and Keynesian Economics. Bus. Econ. Res. J. 10, 77-94. Selim, M., Hassan, M.K., 2019. Interest-free monetary policy and its impact on inflation and unemployment rates. ISRA Int. J. Islam. Financ.

Sidorovich, A., 2018. New economics and political economy. Общество И Экономика 5, 521.

Singerman, D.R., 2016. Keynesian eugenics and the goodness of the world. J. Br. Stud. 55, 538-565.

Siregar, T.H., 2020. Impacts of minimum wages on employment and unemployment in Indonesia. J. Asia Pacific Econ. 25, 62-78.

smadav2021rev1462, n.d.

Smith, M., Yagan, D., Zidar, O., Zwick, E., 2019. Capitalists in the twenty-first century. Q. J. Econ. 134, 1675-1745. 


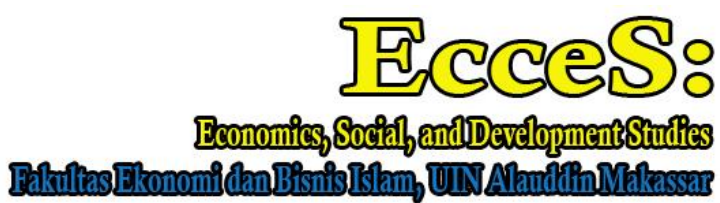

Volume 8 Number 2 Ed. Desember 2021 : page: 175-194 p-ISSN: 2407-6635 e-ISSN : 2580-5570

Sotomayor, O.J., 2021. Can the minimum wage reduce poverty and inequality in the developing world? Evidence from Brazil. World Dev. 138, 105182.

Spiritus, K., Approach, A., 2016. Turkish Economic Review 3.

Stahl, R.M., 2019. Economic Liberalism and the State: Dismantling the Myth of Naïve Laissez-Faire. New Polit. Econ. 24, 473-486.

Szafranek, K., Hałka, A., 2019. Determinants of Low Inflation in an Emerging , Small Open Economy through the Lens of Aggregated and Disaggregated Approach Determinants of Low Inflation in an Emerging , Small Open Economy through the Lens of Aggregated and Disaggregated Approach. Emerg. Mark. Financ. Trade 00, 1-18.

Tenzin, U., 2019. The Nexus Among Economic Growth, Inflation and Unemployment in Bhutan. South Asia Econ. J. 20, 94-105.

Terziev, V., 2019. Factors influencing employment and unemployment policies in Bulgaria. IJASOS-International E-Journal Adv. Soc. Sci. 5.

Thustrup Kreiner, C., Reck, D., Ebbesen Skov, P., 2020. Do lower minimumwages for young workers raise their employment? Evidence from a danish discontinuity. Rev. Econ. Stat. $102,339-354$

To, A., Of, C., 2016. C Lassicals Versus K Eynesians : 1-15.

Tumanoska, D., 2020. The Relationship between Economic Growth and Unemployment Rates: Validation of Okun's Law in Panel Context. Res. Appl. Econ. 12, 33-55.

Turnell, S., n.d. Realism.

Üşenmez, Ö., 2017. Turkey: In the Midst of Crisis, Between Liberal Utopia and Keynesian Regulation. Siyasal Bilim. Derg. 5, 245-262.

Van, H.T., Huu, A.T., 2018. Liberal reform \& economic growth: Current issues and linkages $10,109-118$.

Vukmirović, V., Kostić-Stanković, M., Pavlović, D., Ateljević, J., Bjelica, D., Radonić, M., Sekulić, D., 2021. Foreign Direct Investments' Impact on Economic Growth in Serbia. J. Balk. Near East. Stud. 23, 122-143.

Wahyuningsih, D., Yunaningsih, A., Priadana, M.S., Darma, D.C., Purwadi, P., 2020. Why are Unemployment and Poverty Still Happening in Borneo Island, Indonesia? Int. J. Econ. Financ. Issues 10, 235. 
Murtiadi Awaluddin, I/ham, Rulyanti Susi Wardhani, Andi Sylvana, Controlling the Unemployment Rate in South Sulawesi

Wallerstein, I., 2019. The rise and future demise of the world capitalist system: Concepts for comparative analysis. Towar. a Just World Order 1, 113-139.

Wandel, J., 2019. Do free trade agreements promote sneaky protectionism? A classical liberal perspective. Int. J. Manag. Econ. 55, 185-200. 